\title{
Decentralized Solid Waste Management in Urban Areas: A Review
}

\author{
Slesha N. Desai ${ }^{\# *}$ and Mitali A. Shah" \\ \#Civil engineering Department, SCET, Surat, India \\ Received 02 Nov 2017, Accepted 01 Jan 2018, Available online 02 Jan 2018, Vol.8, No.1 (Jan/Feb 2018)
}

\begin{abstract}
Composting is the cheap and best method for disposal of organic Waste and Converts it in to valuable product. In latest world, stable waste management has grown to be one of the major problems in the course of the good environment. With the development of human civilization and the rapid increase of the population, the sources of waste are more than one and the garbage generated become more complicated, as a result the environment is becoming infected daily. To eliminate such type of dangerous environment and health risks solid waste have to be taken care of through order of several components and then they're handled one at a time available for the reused or recycled site. Mechanical composting process was used to recycle the solid waste and to get fertilizer as an end product. In this paper, many of successful decentralized composting units in Surat are analyzed and its end product as fertilizer analyzed and nitrogen (N), phosphorus $(P)$ and potassium (K) or NPK value obtained. Fertilizer could be used as soil conditioner and in gardening too.
\end{abstract}

Keywords: Organic Waste; decentralized composting; Municipal Solid Waste management, mechanical composting

\section{Introduction}

Many Indian cities face the serious problem of solid waste management (SWM) due to rapid urbanization and are struggling to find effective answers to improve people's standard of living. Currently, Indian cities generate more than $1.70,000$ metric tons, that is, approximately 62 million tons of municipal solid waste per day. Composting is the natural process of decomposing and recycling organic material into a soil amendment rich in humus known as compost. For any company or institution that produces food waste, this organic material can be easily decomposed into high quality compost. Fruits, vegetables, dairy products, grains, bread, unbleached paper napkins, coffee filters, egg shells, meat and newspapers can be composted. So Compost is well decomposed organic waste such as plant waste, animal manure and land from the urine of the livestock hut

The segregation of waste at the source ensures that the waste is less contaminated and it can be collected and transported for further processing. Segregation of waste also optimizes waste processing and treatment technologies. That results in a high proportion of segregated material that could be reused and recycling, leading to lower consumption of virgin material. A various composting schemes of different scale, type

*Corresponding author Slesha N. Desai is a M.E Scholar (Environmental Engineering Department; ORCID ID: 0000-00018428-2145) and Mitali A. Shah is working as Assistant Professor DOI: https://doi.org/10.14741/ijcet.v8i01.10881 and organizational structure currently exist in the country, a general overview is lacking and very little independent site-specific information is available. The objective of the study is to document the innovative decentralized practices in managing the municipal solid waste with emphasis on quantity and types, total waste generated, quantity of compost prepared institutional arrangements, and financial aspects to analyze the feasibility of replicating more of those innovative practices by the waste management authorities in Bengaluru city [Pavan et al, 2014].

\section{A. Decentralized solid waste management (DSWM)}

The Decentralized Solid Waste Management (DSWM) is a system to provide a clean environment and hygienic living conditions by reducing the amount of waste at the source. It involves the management of municipal solid waste by several small waste management centers within the locality.

Decentralized organic Solid Waste (SW) composting promotes green growth, reduces GHG emissions and also reduces transportation of organic SW to waste disposal site. In order to encourage innovation and adoption of decentralized waste recycling solutions, government may consider fiscal and financial incentives for setting up and operation of 'Garbage to Garden' and 'Garbage to Gas'

Waste management systems at the decentralized community level are preferred to centralize waste management solutions under certain circumstances. 
Decentralized waste management systems. Municipal Solid Waste in a centralized location, with the corresponding reduction in costs transport and intermediate storage

\section{B. Technologies for DSWM Treatment}

- Recycling of waste

- Decentralized Composting

- $\quad$ Pit Composting

- Vermi Composting

- Small Scale Anaerobic Digestion

- Mechanical composting

\section{Methodology}

\section{A. Description of study area}

Surat covers 326.515 sq.km of zone out of which South zone (Udhna) covers 61.764 sq.km i.e.18\% of the city range. Surat had a populace of 4.6 million at the 2011statistics, out of which south zone had a Populace of about 7 lakh. It is the eighth biggest city and ninth biggest metropolitan range of India. The City enrolled an annualized GDP development rate of $11.5 \%$ over the seven monetary years somewhere around 2001 and 2008. The city has 2.97 million web clients which are around $65 \%$ of aggregate populace. Surat has a thickness of 13680 persons/sq.km out of which south zone has a thickness of 12311.04 persons/sq.km. Surat has a ghetto populace of 481658 out of which south zone has a ghetto populaceof76025. In Surat City (in year2015), 1575 MT MSW is producedforeachday. Outofthem,1499.44MT/day waste was gathered (Average of $01 / 04 / 13$ to $31 / 03 / 14$ ) by Surat Municipal Corporation (SMC). (Source: www.suratmunicipal.gov.in).

Mechanical composting is a process designed to optimize the use of resources remaining in residual waste. Usually, it is designed to recover materials for one or more purpose, and to stabilize the organic fraction of residual waste. The benefits of this process are that materials and energy may be recovered, void space requirements are reduced and gas and leachate emissions from landfill are significantly reduced. The mechanical composting phase involves segregation and conditioning of wastes.

\section{B. Composting Process}

The composting process was mechanical composting system, which produced finished compost daily. In the process segregation at source was done with organic waste and dry waste. Mechanical composter placed at the common area of society, vegetable market, etc. organic waste is apply from the one side of the composter and after switching on ; the end product will come out as fertilizer from the other side of the mechanical composter.

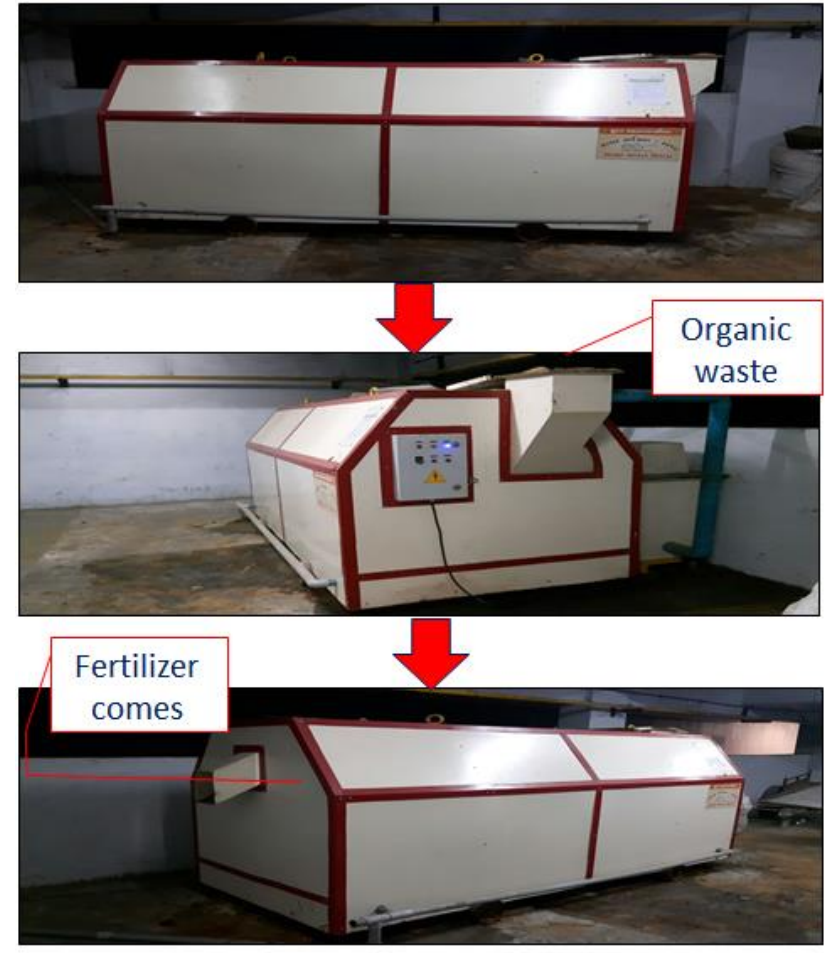

Figure 1: Process of Mechanical Composting

Table 1: Mechanical Composting In Surat City

\begin{tabular}{|c|c|c|c|}
\hline $\begin{array}{l}\text { Sr. } \\
\text { no. }\end{array}$ & $\begin{array}{l}\text { Name of } \\
\text { the zone }\end{array}$ & $\begin{array}{c}\text { Location of OWC } \\
\text { machines }\end{array}$ & $\begin{array}{c}\text { Capacity of OWC } \\
\text { machines }\end{array}$ \\
\hline 1 & \multirow{2}{*}{ South Zone } & $\begin{array}{c}\text { Pandesara Housing } \\
\text { Market }\end{array}$ & 100 Kg Per Day \\
\hline 2 & & $\begin{array}{l}\text { Sonal Ward Vegetable } \\
\text { Market, Pandesara }\end{array}$ & 250 Kg Per Day \\
\hline 3 & \multirow{2}{*}{$\begin{array}{l}\text { South West } \\
\text { Zone }\end{array}$} & $\begin{array}{l}\text { Althan Community } \\
\text { Hall, Bhatar }\end{array}$ & 100 Kg Per Day \\
\hline 4 & & $\begin{array}{l}\text { Vanita Vishram, Athwa } \\
\text { Gate }\end{array}$ & 100 Kg Per Day \\
\hline 5 & $\begin{array}{l}\text { South East } \\
\text { Zone }\end{array}$ & $\begin{array}{l}\text { Vegetable Market } \\
\text { Dindoli, Opp. Bus } \\
\text { Station }\end{array}$ & 250 Kg Per Day \\
\hline 6 & North Zone & $\begin{array}{l}\text { Vegetable Market } \\
\text { Singanpore, Opp. } \\
\text { Health Centre }\end{array}$ & 250 Kg Per Day \\
\hline 7 & West Zone & $\begin{array}{c}\text { Sarojini Naidu } \\
\text { Vegetable Market, } \\
\text { Palanpur Patia }\end{array}$ & 250 Kg Per Day \\
\hline 8 & \multirow{3}{*}{ East Zone } & $\begin{array}{c}\text { Bhaktinagar Vegetable } \\
\text { Market }\end{array}$ & 250 Kg Per Day \\
\hline 9 & & $\begin{array}{c}\text { Akshaypatra, Aai Mata } \\
\text { Nagar }\end{array}$ & 100 Kg Per Day \\
\hline 10 & & Smmimer Hospital & 100 Kg Per Day \\
\hline 11 & & $\begin{array}{c}\text { Anjana Transfer } \\
\text { Station, Limbayat, } \\
\text { Surat }\end{array}$ & 1000 Kg Per Day \\
\hline
\end{tabular}

\section{Economic aspects of decentrlized swm system}

If segreagate of solid waste is done at source than 60$70 \%$ cost will be reduced with compare to total solid waste cost as per segregation of solid waste, organic waste will be compost with mechanical composting \& it is recycleable as composting.

\section{Result}

Organic sample was collected from anjana one of the house hold area where mechanical composter was placed and where segregation was done as dry waste 
and wet waste. After completing process fertilizer comes as an end product and within standard limit. Result Analysis is as follows:

Table 3: Analysis of sample

\begin{tabular}{|c|c|}
\hline Parameter & No.1 \\
\hline Total N (\%) & 0.97 \\
\hline Total P (\%) & 0.36 \\
\hline Total K (\%) & 1.44 \\
\hline
\end{tabular}

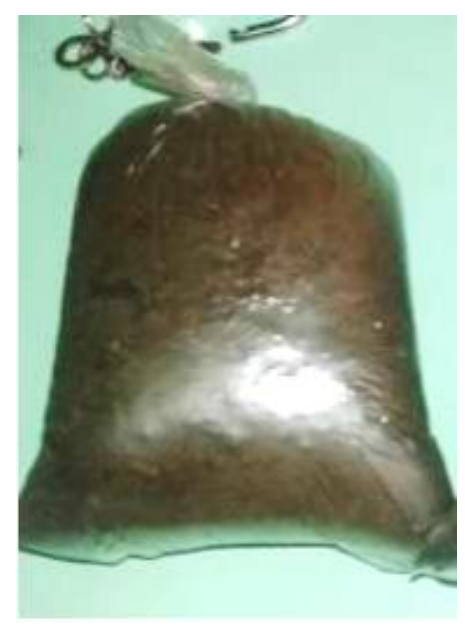

Figure 3: fertilizer Sample as an end product

\section{Conclusion}

The present study suggest that segregation at source as organic waste and dry waste could be the beneficial in solid waste management. Mechanical composting machine reduce the workload of worker and its time consuming process. Mechanical composting process could be the cost effective if $50-60 \%$ segregation can be done. This is the most solution seeking problem of the country today, since social, economical as well as the health environment is seriously affected by the improper solid waste treatment technologies in the state.
The end use of the output from the mechanical composting process is making it versatile in terms of recycle of solid waste.

\section{References}

Renu Pawels, Asha. P.Tom, 2013, Assessment of Technological Options for Solid Waste Treatment in Kerala , international Journal of Scientific and Research Publications, Volume 3, Issue 8

Pavan, H B Balakrishna, 2014, Decentralized Composting of Municipal Solid Waste in Bengaluru City - An Overview,International Journal of Research In Engineering And Technology

Abira Mukherjee, Goutam Kumar Bose, Biswajit Mandal, Avijit Ghosh, 2016, Review on Biodegradable Kitchen Waste Management, International Journal of Research In Engineering And Technology

K.R. Atalia, D.M. Buha, K.A. Bhavsar, N.K. Shah, 2015, Review on Composting of Municipal Solid Waste, Journal of Environmental Science, Toxicology And Food Technology, Volume 9, Issue 5

Kumar S., Mondal A.N., Gaikwad S.A., Sukumar Devotta and Singh P.N., 2004, Qualitative Assessment of Methane Emission Inventory from Municipal Solid Waste Disposal Sites: A Case Study, Atmospheric Environment, 38, 49214929.

Zhang M., Heaney D., Henriquez B., Solberg E., Bittner E., 2006, A Four-Year Study on Influence of Biosolids/MSW Cocompost Application In Less Productive Soils In Alberta: Nutrient Dynamics, Compost Sci. Util., 14 (1), 68-80.

Sharholy M., Ahmad K., Mahmood G., Trivedi R.C., 2006, Development of Prediction Models for Municipal Solid Waste Generation for Delhi City. In: Proceedings of National Conference of Advanced In Mechanical Engineering (AIME-2006), Jamia Millia Islamia, New Delhi, India, , 1176-1186.

Das D., Srinivasu M., Bandyopadhyay M., 1998, Solid State Acidification of Vegetable Waste, Indian Journal of Environmental Health, 40 (4), 333-342.

Christain Zurbrügg, Silke Drescher, Almitra Patel, H.C. Sharath Chandra, 2004. Decentralized Composting of Urban Waste-An Overview of Community And Private Initiatives In Indian Cities, Waste Management, 24, 655662 